\title{
Length-Weight Relationships, Condition Factor and Fecundity of the West Africa Freshwater Crab, Sudanonautes africanus (Milne-Edwards 1883), in Western Nigeria
}

\author{
O. A. Bello Olusoji ${ }^{1 *}$, O. J. Anifowose ${ }^{1}$ and M. Y. Sodamola ${ }^{2}$ \\ ${ }^{1}$ Fisheries and Wildlife Department, Federal University of Technology, Akure, Nigeria \\ ${ }^{2}$ Federal College of Agricluture, Moore Plantation, Ibadan, Nigeria \\ *Corresponding author
}

\begin{abstract}
The length-weight relationships, condition factor and fecundity of the West-African freshwater crab, Sudanonautes africanus, was studied from different freshwater bodies within south-western Nigeria. The crabs were separated into males (151) and females (112). The length-weight relationship, condition factors, and fecundity of the crabs were determined. Growth parameters $a$ and $b$ of the length-weight relationship, (LWR) w $=\mathrm{aL}^{\mathrm{b}}$, for $S$. africanus was $0.889,5.029$ and 0.713 for males, females and entire population, respectively. The values of $b$ estimated were $2.475,3.185$ and 2.567 for males, females and whole population, respectively. The regression equation for the $\mathrm{LWR}$ are $\mathrm{W}=-0.046+2.475 \mathrm{~L}$ for males, $\mathrm{W}=0.717+3.185 \mathrm{~L}$ for females and $\mathrm{W}=-0.147+2.567 \mathrm{~L}$ for the total crab population. The coefficient of determination of males, females and entire population were $0.716,1.049$ and 0.699 , respectively, showing a strong correlation between the variables. There was a strong relationship $\left(r^{2}=0.81\right)$ between length and weight of males and females and the entire crab population. The LWR was allometric for all crabs. Results also show that there is a weak correlation $\left(r^{2}=0.36\right)$ between fecundity and total body weight $(\mathrm{BW}) /$ carapace length $(\mathrm{CL})$ of the crabs. The length-weight distribution pattern did not show remarkable differences between species, sexes, and populations. Length-weight relationships have no influence on the fecundity. Mean $( \pm$ SE) fecundity $(292.8 \pm 76.07$ eggs $)$ was positively related $\left(r^{2}=0.75\right)$ to CL. Fecundity ranged between 120 and 449 eggs with a mean diameter of $1.66 \mathrm{~mm} \pm 0.068 \mathrm{~mm}$. No relationship between egg size and carapace length was found. There was no significant difference $(P>0.01)$ in condition factors between the sexes.
\end{abstract}

\section{Introduction}

Crab culture is yet to be developed in Nigeria, with the vast number of crabs present in both marine and freshwater bodies (Bello-Olusoji et al., 2006). Crabs are commonly harvested with crab pots, gill/set nets, and traps by local fishermen from streams, ponds, reservoirs and rivers. In many areas throughout swoutheast Asia crab production is a significant industry especially in the Philippines, Vietnam, Indonesia, Sarawak and elsewhere in southeast Asia (Radhakrishnan, 2000). They are easily bred in captivity, though the main constraint is the reliable supply of crablets. Live mud crab, Scylla serrata, fetch market prices of around USD10 per $\mathrm{kg}$ in Asian markets. The crabs can grow from juvenile to adult size in 4-6 months in pond culture system, depending on the crab species, with all the water quality parameters requirements met; thus, indicating that the crab can be cropped twice in a year.

The West African freshwater crab belonging to family Potamonautidae, with over 88 species, is present in all the streams 
and river systems across Africa (Cumberlidge, 1999). Genus Sudanonautes is found in West Africa from Là Cote d'Ivoire to Nigeria, Cameroon to Democratic Republic of Congo and southern Sudan (Cumberlidge, 1999). Crabs play a critical role in the aquatic food web as voracious, opportunistic predators, and as an important source of prey for many different species (Guillory, 2001). Juvenile and adult crabs are preyed upon by a variety of fishes, turtles and alligators, seabirds, and even mammals, including raccoons and river otters (Guillory et al., 2000; MDDNR, 2001).

In Nigeria, the only major crab fishery operation is the fishing and exportation of the marine portunid crabs (Bello-Olusoji et al., 2006). FAO (2002) estimated the exportation to worth at least $\$ 10$ million. Farming of fresh water crabs by fish farmers can complement traditional fishing. The culturing of the crabs can be seen as job creation ventures in which women and the youth can play an important role. It will serve as income generation as well as protein production for people.

The length-width/weight relationship is regarded as more suitable for assessing not only fish, but also crustacean (Sukumaran \& Neelakantan, 1997; Tabash, 2001). The relationships between carapace length and weight of the crabs have many uses. They are often used to calculate the standing stock biomass, condition indices, analysis of ontogenetic changes and several other aspects of crustacean population dynamics (Atar \& Seçer, 2003). In addition they are used for the management of population. According to Lagler (1968), the relationship can be used to estimate the recovery of edible meat from crabs of various sizes. Body weight, total length and carapace length are the most frequently used dimensions in the study of crustaceans (Sukumaran \& Neelakantan, 1997).

The stock status of Sudanonautes africanus is still unknown, due to dearth of information on the population structure, neither is there any detailed information about the biology of these crabs presently in Nigeria. Moreover, there are non existing current information on the length-weight relationships and condition factors from the family, Potamonidae. In this study, therefore, some aspects of the population ecology, such as length-weight relationships, condition factors, and fecundity of $S$. africanus were studied.

\section{Materials and methods}

Study area

West African freshwater crabs, $S$. africanus, were collected from major streams supplying four major fish farms; these are Fisheries and Wildlife Departmental Fish Farm, Federal University of Technology, Akure (Akure coordinates $7^{0} 15^{\prime}$ N, $5^{0} 15^{\prime}$ E); Sunshine Fisheries, Akure; Ibule Farm, Ibule; and Nazarene Fish Farm, Ibadan. The crabs were collected with the assistance of fishermen using artisanal baited pots, traps and hands (manual) to pick and dislodge them from their nest. Samples collected daily were transported to the Fisheries and Wildlife fish farm and kept in concrete tanks filled with water at room temperature $\left(26.5-28.4{ }^{\circ} \mathrm{C}\right)$ for analysis. The male and female sexes were identified after Barnes (1974).

\section{Length-weight determination}

The total body weight (BW) of the crab was measured to the nearest $0.1 \mathrm{~g}$ using a weighing balance (HANA POWER. KCA), 
while the carapace length (CL) was measured with a laboratory measuring board to the nearest $0.1 \mathrm{~cm}$. The length-weight relationship was estimated using the equation:

$$
\mathrm{W}=\mathrm{aL}^{\mathrm{b}}
$$

where $\mathrm{W}$ is the weight, $a$ is the intercept, $\mathrm{L}$ is carapace length and $b$ is the slope. The value of $a$ and $b$ were computed from the $\log$ transformed values of length and weight, i.e.

$\log \mathrm{W}=\log \mathrm{a}+\mathrm{b} \log \mathrm{L}$,

where $\mathrm{W}=$ weight $(\mathrm{g})$ of the crabs, $\mathrm{L}=$ horizontal carapace length (using the linear regression routine of Microsoft Office Excel in PC windows (2003). The parameters $a$ (intercept) and $b$ (slope) were estimated by linear regression based on logarithms; log $(\mathrm{W})=\log (\mathrm{a})+\mathrm{b} \log (\mathrm{L})$. The significance of regression was assessed by analysis of variance (ANOVA). Equations expressing the width/length-weight relationships of $S$. africanus were calculated in relation to sex. For testing possible significant $(P>0.01)$ differences between the sexes Student's ttest was used for comparison of the two slopes. FORTRAN program Mature II computer technique was used to estimate the size at sexual maturity.

The Fulton's condition factor (cf) was calculated according to Bagenal (1978) with the formula;

$$
\mathrm{K}=100 \mathrm{~W} / \mathrm{L}^{3} \text {. }
$$

where $\mathrm{K}$ is the condition factor (cf), $\mathrm{W}$ is the total body weight ( $\mathrm{BW}$ ), $\mathrm{L}$ is the carapace length (CL) and 3 is a constant.

\section{Determination of fecundity}

Females (using the shape of abdomen (Plate $1 \mathrm{a}, \mathrm{b}$ and $\mathrm{c}$ ) and numbers of swimmerets with eggs were randomly selected; the eggs were dislodged from the brooding chamber using scalpel. Fecundity was determined by total counts according to Bagenal (1978) and Radhakrishnan (2000).

\section{Results}

Identification and distinction between male and female

Two hundred and sixty-three crabs were collected, male crabs have narrow abdomen while females have wider abdomen where pleopods are retained (Plates 1a, b, and c). The sex ratio of the $S$. africanus collected was 4:3, with males (151) and females (112), showing that there were more males than females.

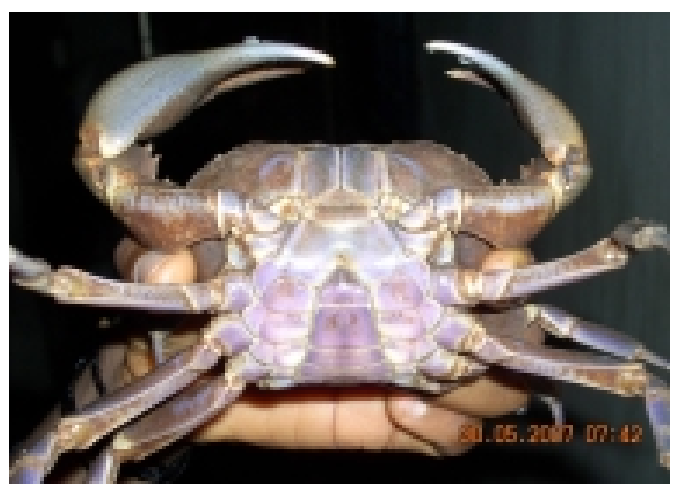

Plate 1a. Male S. africanus

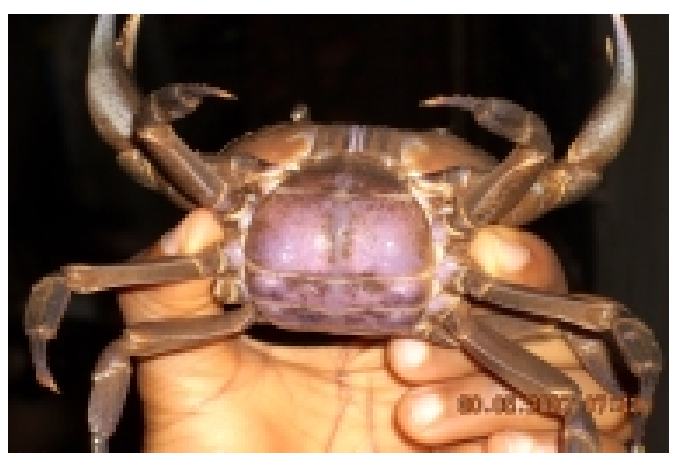

Plate 1b. Female S. africanus 


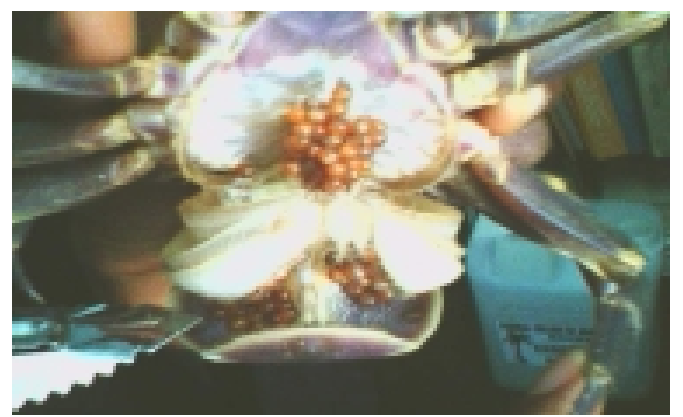

Plate 1c. Berried Female crab showing the brooding chamber with fertilized eggs

\section{Length-weight relationship}

The result also showed that $S$. africanus grow between the range of $5.0 \mathrm{~cm}$ and 8.0 $\mathrm{cm}$ (carapace length) as shown in Table 1 . The weight range of $S$. africanus was 50 $175 \mathrm{~g}$ while it was 50-175 $\mathrm{g}$ and $50-150 \mathrm{~g}$ for males and females, respectively, as shown in Table 1. This result was compared to the blue crab, $C$. sapidus, whose weight range was 8.92-448 g (Atar \& Seçer, 2003). The results showed that marine crabs are bigger than freshwater crabs. It was observed that the growth pattern of $S$. africanus was allometric (Table 2) using the regression co-efficient $b$ to determine it. The values of $b$ are $2.475,3.185$ and 2.567 for males, females and the total population, respectively.

Fig. 3a, b and c showed the LWR of the entire crab population, male and female crabs, respectively. The co-efficient of determination $\left(R^{2}\right)$ in LWR are $0.679,0.778$ and 0.701 for males, females and the entire population, respectively (Table 2 ). This is

TABLE 1

Carapace length and weight characteristics (mean, minimum and maximum) for $\mathrm{S}$. africanus

\begin{tabular}{lccccccccc}
\hline & \multicolumn{4}{c}{ Carapace length $(\mathrm{CL}, \mathrm{cm})$} \\
Sex & \multirow{2}{*}{ No. } & Mean & SE & Min. & Max. & Mean & SE & Min. & Max. \\
\hline Male & \multirow{2}{*}{151} & 6.7 & 0.056 & 5.0 & 8.0 & 102.0 & 2.067 & 50.0 & 175.0 \\
Female & 112 & 6.7 & 0.032 & 5.2 & 7.8 & 90.5 & 2.012 & 50.0 & 150.0 \\
Total & 263 & 6.7 & 0.012 & 5.0 & 8.0 & 96.8 & 1.078 & 50.0 & 175.0 \\
\hline
\end{tabular}

$(\mathrm{SE}=$ Standard error $)$

TABLE 2

Parameters of the relationship $\left(W=a L^{b}\right)$ between weight and carapace length $(C L)$ and $c f$ for $\mathrm{S}$. africanus.

\begin{tabular}{llllllllll}
\hline & No. & $a$ & $b$ & $S E(b)$ & $c f$ & $\begin{array}{l}\text { Regression } \\
\text { equation } \\
(B W=a+b C L)\end{array}$ & $r$ & $r^{2}$ & $\begin{array}{l}\text { Growth } \\
\text { pattern }\end{array}$ \\
\hline Males & 151 & 0.889 & 2.475 & 0.0367 & 33.91 & $\mathrm{~W}=-0.046+2.475 \mathrm{~L}$ & 0.836 & 0.679 & Allometric \\
Females & 112 & 5.029 & 3.185 & 0.0308 & 30.09 & $\mathrm{~W}=0.717+3.185 \mathrm{~L}$ & 1.030 & 0.778 & $\begin{array}{l}\text { Allometric } \\
\text { All }\end{array}$ \\
\hline
\end{tabular}

Where $\mathrm{a}=$ Intercept, $\mathrm{b}=$ Regression coefficient, $\mathrm{r}=$ Correlation coefficient, $\mathrm{r}^{2}=$ Coefficient of determination and $\mathrm{cf}=$ Condition factor 
compared to that of blue crabs studied by Atar \& Seçer (2003), which were 0.86 and 0.88 for males and females. Both results indicate that there is more than $50 \%$ significance in length and weight of both crabs.

\section{Condition factor}

Estimated parameters of conversion between the carapace length measurements $(\mathrm{CL}$, in $\mathrm{cm})$ and the mean condition factors by the length and width of the blue crabs and standard errors calculated for sex are given in Table 3. The variation in cf between the sexes was not significant for either equation $(P>0.01)$. The $\mathrm{cf}$ values were 33.91, 30.09 and 32.19 for males, females and combined data, respectively (Table 2). This is compared to the result obtained by Atar \& Seçer (2003) using blue crab, $C$. sapidus, with cf values 48.196 and 5.638. The cf result of $S$. africanus showed the fatness and well being of the crabs.

\section{Fecundity}

Fecundity studies of $S$. africanus show that sexual maturity in gravid females is reached at early sizes ranging from 6.1 to $7.5 \mathrm{~cm}$ (Table 3). Fecundity range in $S$. africanus is $120-449$ and the mean fecundity is $292.8 \pm 67.566$. Fig. 1 and 2 showed the relationships pattern between the fecundity and the crab length and weight, respectively.

\section{Discussion}

During the study period it was observed that there were more males than females due to the reasons mentioned being the reproduction period which is seasonal and coincided with the onset of rainfall. Females mostly reside in their holes taking care of their larvae and young ones while males were found outside searching for food.

The length-weight relationship study carried out by Atar \& Seçer (2003) indicated that blue crabs, Callinectes sapidus, mostly reach legal size of between 11 and $15 \mathrm{~cm}$ in carapace length. Bello-Olusoji et al. (2006)'s work on LWR of portunid crabs, Callinectes pallidus, reported that size ranged between 15.50 and $22.57 \mathrm{~cm}$. Thus, an indication that blue crabs and portunid crabs reach maturity at greater sizes than $S$. africanus, which mature at early sizes. The result of $S$. africanus is compared with the result obtained by Carsen et al. (1996), which showed that sexual maturity occurs at 40$50 \mathrm{~mm}$ carapace length in female Platyxanthus patagonicus. This revealed that $P$. patagonicus reach maturity at early sizes than $S$. africanus. This means that $S$. africanus have a low weight range compared to other crabs.

According to Bello-Olusoji et al. (2006), the weight of adult portunid crabs, $C$. pallidus, ranged from 236 to $324 \mathrm{~g}$, which was greater than that of $S$. africanus. This indicates that dimensions change with

TABLE 3

Weight, length, and fecundity range and mean/gravid females

\begin{tabular}{lllll}
\hline & Weight $(g)$ & Fecundity & length $(\mathrm{cm})$ & Fecundity \\
\hline Range & $62.5-125$ & $120-449$ & $6.1-7.5$ & $120-449$ \\
Mean & 87.5 & 292.8 & 6.76 & 292.8 \\
\hline
\end{tabular}

West African Journal of Applied Ecology, vol. 16, 2009 


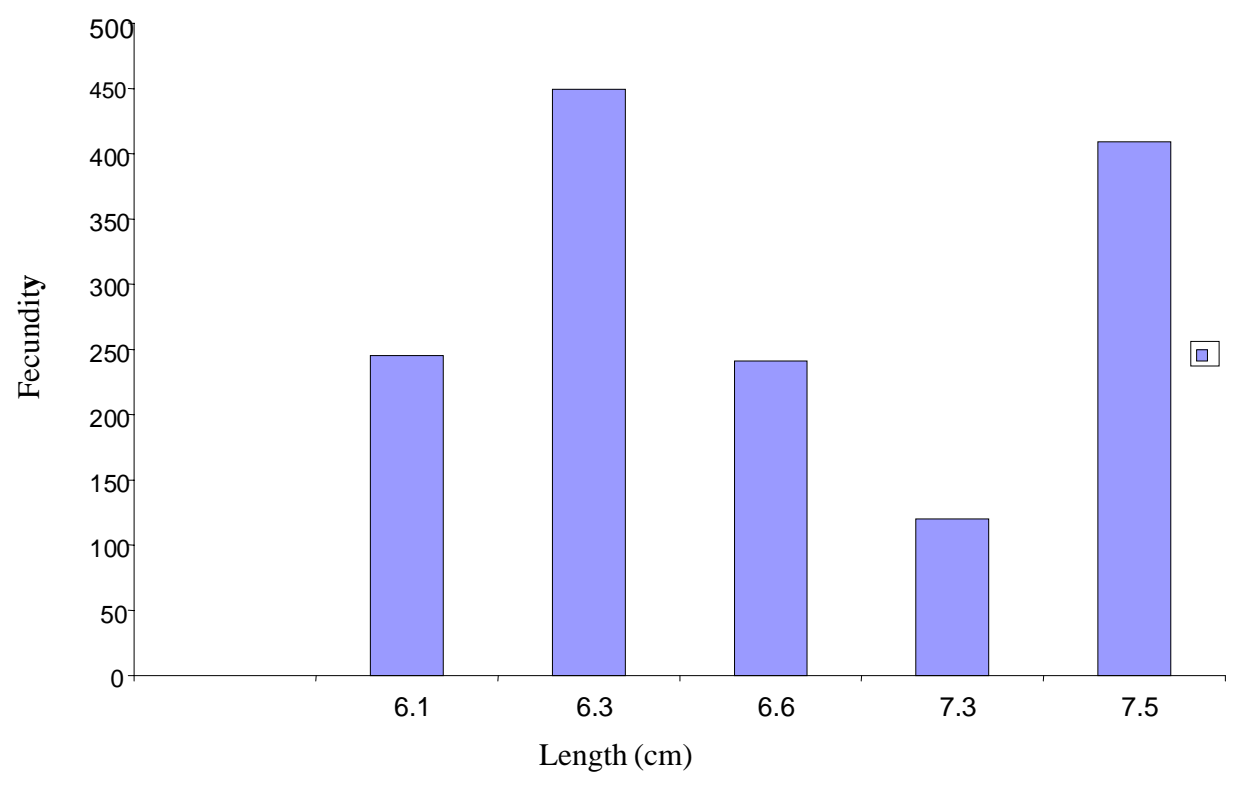

Fig. 1. Fecundity and length relationship of S. africanus

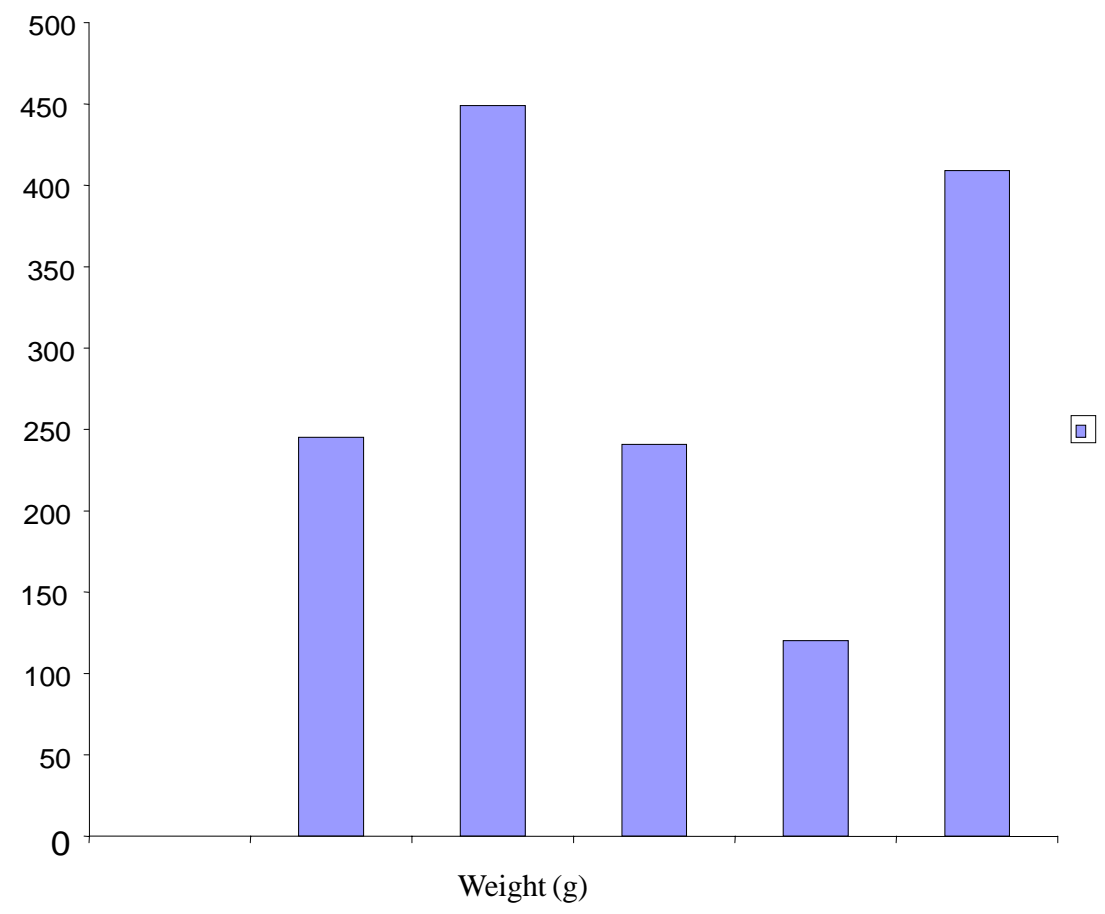

Fig. 2. Fecundity and weight (g) relationship of S. africanus 


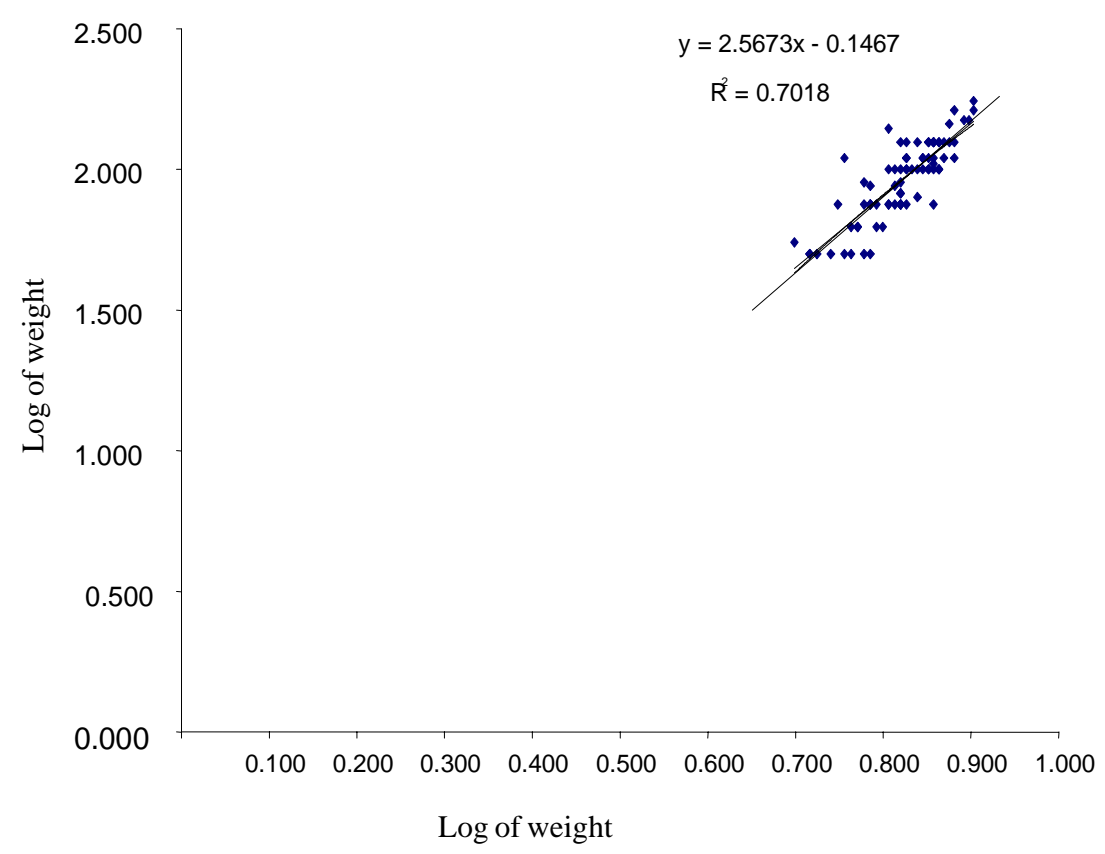

(a) Total population

$\because \ldots$

1.500

_Linear (Log of weight)

1.000

0.500

0.000

$\begin{array}{llllllllll}0.100 & 0.200 & 0.300 & 0.400 & 0.500 & 0.600 & 0.700 & 0.800 & 0.900 & 1.000\end{array}$

Log of length

Log of length

(b) Male crab

West African Journal of Applied Ecology, vol. 16, 2009 
Fig. 3. Length-weight relationship of (a) total crab population, (b) male and (c) female crabs.

growth according to Bagenal (1978), who explained that when co-efficient of regression is greater and or less than 3 , then growth is allometric but when equal to 3 , then the growth is isometric. The values of $b$ ranged form 2.04 to 3.24 for $C$. sapidus from Georgia (Stickney, 1972), and it shows similarities with the result of $C$. sapidus in Beymelek Lagoon. (Atar \& Seçer, 2003). These results are almost similar to that of $S$. africanus. Growth was isometric (3.04) value in the length-weight relationship study of portunid crabs, C. pallidus, from the Gulf of Guinea (Bello-Olusoji et al., 2006) which is different from all the above mentioned results. Change of $b$ value depends primarily on the shape and fatness of the species.
Various factors may be responsible for the differences in parameters of length-weight relationships among seasons and years, such as temperature, salinity, food (quantity and quality), sex and maturity stage.

When compared to male hermit crabs, Diogenes pugilator reaches sexual maturity at very small sizes (Mánjon-Cabeza \& Garcia-Raso, 2000). For male $P$. patagonicus crabs, possible size at sexual maturity is between 4.0 and $5.0 \mathrm{~cm}$ carapace length (Carsen et al., 1996). Carsen et al. (1996) explained that in P. patagonicus, ovigerous females reach between 42.7 and $72.0 \mathrm{~mm}$ carapace length and mean fecundity was $97,900 \pm 37,800$ eggs (SD). The difference in fecundity is very wide; 
indicating that fecundity of $S$. africanus is very low compared to other crabs. MánjonCabeza \& Garcia-Raso (2000) also explained that the number of eggs by brood of hermit crab, D. pugilator, is between 9 and 2838. Work on fecundity and egg size data for three species of crabs from Antarctic waters by Morley et al. (2008) indicated that fecundity increase with body size, but reproductive allocation was found to differ significantly between species. The highest relative fecundity $\left(\mathrm{eggs}^{-\mathrm{g}}\right.$ body weight) and smallest egg size was found in Paralomis spinosissima, which is found in shallower waters, whereas the lowest relative fecundity values and largest eggs were recorded in the deeper living species, Neolithodes diomedeae.

There was a weak correlation $\left(r^{2}=0.24\right)$ between the fecundity and weight of gravid S. africanus crabs. Crabs with bigger sizes produce small number of eggs and those with smaller sizes produce large number of eggs because fecundity is independent of the length and weight of the crabs. The relationship between fecundity and female size does not show a potential trend unlike the result of some species of brachyuran (Haynes et al., 1976) and hermit crabs. The regression equations are significant $(P>$ $0.05)$ at both levels of significance for combined data and male data but it was not significant $(P<0.05)$ at both levels for female data.

\section{Conclusion}

In the study, the sex ratio of the crabs was $4: 3$, indicating that males were found mostly going in search for food and mating because of the reproductive period which is seasonal during the onset of rainfall. The length- weight relationship showed that the crab's growth was allometric, indicating that, as the weight increases, the length increases as well, while the length range showed it as an early maturing species. The fecundity does not depend on the length and weight of the crabs. No significant differences were recorded among monthly fecundity values and the cf values, suggesting that the environmental effect in egg production is slight at best. The LWR showed that $S$. africanus is a good candidate for aquaculture though other factors need to be considered apart from reproductive biology. It is also essential for proper assessment and management of resources in the West African freshwaters. The crab, $S$. africanus, possessed a high fecundity, producing many eggs per individual is an indication that they are viable for farm production, and can be bred in captivity, which means that selective breeding (e.g. for rapid growth) can take place to forestall extinction of the population in the near future.

\section{References}

Atar H. H. and Secer S. (2003). Width/Length-weight relationship of blue crab, Callinectes sapidus (Rathburn, 1896). Population living in Beymelek lagoon lake. Turk. J. Vet. Anim. Sci. 443-447.

Bagenal T. B. (1978). Methods of Assessment of fish production in freshwaters, 3rd edn. IBP Handbook No 3. pp. 126-130, 166-169.

Barnes R. D. (1974). Invertebrate Zoology, 3rd edn. W. B. Saunders Company, Philadelphia, London. Toronto. pp. 510-520, 579-610.

Bello-Olusoji O. A., Oyekanmi M, Afunmiso O. M, and Ozorewor M. O. (2006). Length-weight relationship and stomach content of Portunid crabs, Callinectes pallidus (de Rochebrune, 1883) from the Gulf of Guinea. Bowen J. Agric. 3(1): 65-72.

Carsen E. A., Kleiman. S and Marcelo A. S. (1996). Fecundity and relative growth of the crab, Platyxanthus patagonicus (Brachyura: 
Platyxanthidae), in Patagonia, Argentina. J. Crust. Biol. 16(4): 748-753.

Cumberlidge Neil (1999). Modification of the freshwater crabs of West Africa. Family Potamonautidae. IRD. pp. 1-382.

FAO (2002). FAO Year Book Fisheries Statistics Capture Production. FAO, Rome. 713 pp.

Guillory V. (2001). Blue Crab Home Page. Available at: http://www.blue-crab.net.

Guillory V., Perry H. and VanderKooy S. (ed) (2000). The Blue Crab Fishery of the Gulf of Mexico, United States: A Regional Management Plan (Draft). July. Gulf States Marine Fisheries Commission.

Haynes E. K., Watson F. J. and Hopson D. J. (1976). Relation of number of eggs and egg length to carapace width in the brachyuran crabs, Chionoecetes baindi and C. spilis from the south-eastern Bering Sea and C. spilis from Gulf of Saint Lawrence. $J$. Fish. Res. Bd Can. 33: 2592-2595.

Largler K. F. (1968). Capture, Sampling and Examination of Fishes. In Methods for assessment of fish production in freshwaters. (W. E. Ricker, ed.), pp. 7-45. IBP Handbook 3.

Mánjon-Carbeza M. E. and Garcia-Raso J. E. (2000). Reproductive aspects of females of the hermit crab,
Diogenes pugilator (Crustacea: Decapoda: Anomura), from Southern Spain. Abstract pp. 8593.

Maryland Department of Natural Resources (MDDNR) (2001). Blue Crab, Callinectes sapidus (A. K. A. Blue claw crab). Available at http:// www.dnr.state.md.us/fisheries/ education/crab/ bluecrabfacts. html.

Radhakrishnan A. (2000). The eggs of marine crabs - An unexploited resource. NAGA, ICLARM Q.J. 23( 3): 4-5.

Stickney R. R. (1972). Length-weight relationships for several fishes and invertebrates in Georgia coastal waters with condition factors for fish species. Skidaway Institute of Oceanography Savanna, Georgia.

Sukumaran K. K.and Neelakantan B. (1997). Length-weight relationship in two marine portunid crabs, Portunus sanguinolentus (Herbst) and Portunus pelagicus (Linnaeus) from Kamataka coast. Indian J. Mar. Sci. 26: 39-42.

Tabash F. A. (2001). Assessment and Ecological Characterization of the Blue Crab (jaiba, Callinectes arcuatus) in the Gulf of Nicoya, Costa Rica. www.una.ac.cr/biol/unalaw/english/crab.htm 